\title{
STUDENT SATISFACTION PROCESS IN VIRTUAL LEARNING SYSTEM: Considerations Based In Information And Service Quality from Brazil's Experience
}

\author{
Fábio Nazareno MACHADO-DA-SILVA \\ Instituto Federal de São Paulo (IFSP), BRAZIL \\ Fernando de Souza MEIRELLES \\ Fundação Getulio Vargas (EAESP/FGV), BRAZIL \\ Douglas FILENGA \\ Universidade Metodista de São Paulo, BRAZIL \\ Marino Brugnolo FILHO \\ Fundação Getulio Vargas (EAESP/FGV), BRAZIL
}

ABSTRACT

Distance learning has undergone great changes, especially since the advent of the Internet and communication and information technology. Questions have been asked following the growth of this mode of instructional activity. Researchers have investigated methods to assess the benefits of e-learning from a number of perspectives.

This survey assesses the associations among the system quality, information quality, and service quality on student satisfaction and use of systems in virtual learning environments using the e-learning success model adapted by Holsapple and Lee-Post from the Delone and McLean $(1992,2003)$ model as a theoretical basis.

The survey was carried out by means of an online program offered to 291 students from public and private institutions from several regions of Brazil. Confirmatory Factor Analysis and Structural Equation Modeling were used for data analysis in order to understand the student satisfaction process in virtual learning system. Findings show that variations in system quality, information quality, and service quality influence the use of the system, and the User Satisfaction construct had $89 \%$ of variance explained by Information Quality and Service Quality.

Many of the benefits of distance learning programs are related to students' satisfaction and the intensity with which they make use of the learning system. With awareness of the indicators that are antecedents of these variables, education executives can plan investments that meet the most significant demands and use the information to deal with one of the major problems in distance learning: the dropout rate. Future researches should study this subject longitudinally.

Keywords: Distance education; student satisfaction; quality in e-learning. 


\section{INTRODUCTION}

Distance learning has undergone drastic changes in recent decades with respect to both technology and teaching-learning method. Students have sought distance learning, which is defined as collaborative learning, whether computer-based or not, that offers synchronous and/or asynchronous tools and is characterized by physical distance between students and teachers (Kelly, 2011).

Considering the dropout rate as a frequent factor in distance courses as stated in different articles, accomplishment of the courses can be influenced by factors such as the correct use of proper media to facilitate interactivity between teachers and students and among students.

How then should the success of web-based distance learning courses be evaluated? Attempts to solve this important question have resulted in many anecdotal studies assessing the impact of distance learning programs using measures such as learning benchmarks (Pittinsky and Chase, 2000), learning opportunities (Jewett, 1998), learning styles (Byrne, 2002), learning environment (Jing et al., 2002; Wang 2003), learning outcomes (McClelland, 2001; Motiwallo and Tello, 2000; Teh, 1999), teaching practices (Owston and Wideman, 1998; Savenye, Olina, and Niemczyk, 2001), and cost-benefits (Lawhead et al., 1997; Smith, 2001). Yet, the complex task of comprehensively evaluating distance-learning environments remains a challenge.

Holsapple and Lee-Post (2006) proposed a success-assessment model for distance learning that utilized interrelated dimensions and promised a holistic analysis of distance-learning success. The original study was based on the assessment of the success of information systems byDelone and McLean (1992) and their later revision (Delone and McLean, 2003). This model allowed for a study targeted to the distance-learning context and analyzed from the e-learning-success perspective. This study assessed the relation of system quality, information quality, and service quality on students' satisfaction and their use of systems in virtual learning environments, using the adapted e-learning-success model of Holsapple and Lee-Post (2006).

Also applied structural equation modeling techniques, disclosed the internal consistency of the constructs, and assessed whether and why causal relationships among them exist. Findings main contribute to the scientific development of this area of knowledge, and are likely to impact society by contributing to effective distance-learning programs that are geared toward meeting the actual needs of students.

\section{MODEL OF RESEARCH AND HYPOTHESES}

System Quality is characterized by factors related to the software managing the distance course, such as ease of use, stability, and visual resources (Holsapple and Lee-Post, 2006).

Information Quality refers to characteristics about the course content, and Service Quality comprises actions of the subjects who are part of the teaching-learning process, such as teachers, tutors, and technicians. 
Jointly, both these dimensions, information and services, promote higher satisfaction and greater intention to use the resources delivered in the virtual environment (Ozkan and Köseler, 2009).

The Use construct refers to the frequency with which the user accesses the resources offered by the virtual learning environment, and User Satisfaction is the positive feeling derived from participating in the course (Holsapple and Lee-Post, 2006). (Ozkan and Köseler, 2008) identified a relationship among multidimensions in which system quality, information quality, and service quality are independent variables that influence students' use of and satisfaction with virtual learning environments.

Lee-Post (2009) reinforced the causality of the independent dimensions indicated in this study and termed them Satisfaction, Benefits Perceived, and Intention of Use. In research on the antecedents of continuity of use in distance learning, Shee and Wang (2011) disclosed that "information quality, technology quality, perceived usefulness, and satisfaction with the system influence the intention to use."

In this study the hypotheses are related with the objectives of the study and are illustrated in Figure 3. Explanations about the hypotheses are shown in the Theoretical Basis session.

$>$ H1: System Quality is positively associated with the Use of Information Systems;

$>$ H2: System Quality positively influences User Satisfaction;

$>$ H3: Information Quality positively influences Use;

$>$ H4: Information Quality positively influences User Satisfaction;

$>$ H5: Service Quality positively influences Use;

> H6: Service Quality positively influences User Satisfaction.

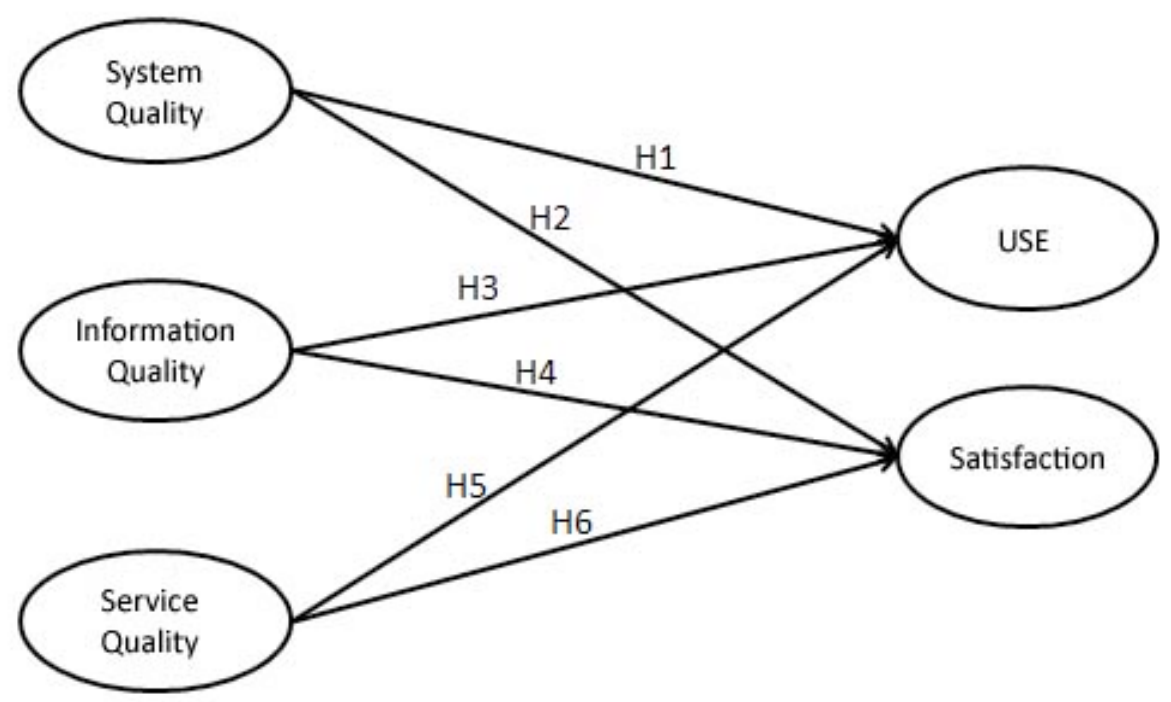

Figure: 3

Model of antecedents of satisfaction and use of e-learning to be tested 


\section{Information Systems Success Model-ISSM}

(DELONE and McLEAN, 1992; DELONE and McLEAN, 2003)

Among the various studies that attempted to identify the factors that influence user satisfaction and the success of an information system, the Information Systems Success Model by Delone and McLean $(1992,2003)$ is deemed as one of the most comprehensive model, and is used worldwide. Consolidated from the data found mainly in studies in the Information Systems (IS) area (Wang, 2003), the model introduces six dimensions that jointly promise to evaluate the success of an information system. These dimensions are System Quality, Information Quality, Utilization, User Satisfaction, Individual Impact, and Organizational Impact. This model offers a new approach to understanding the main aspects of information-system success. It has been tested, validated, altered, and criticized, and it is a basis for the construction of other models.

In light of ongoing research and the emergence of e-commerce, Delone and McLean (2003) extended and streamlined the original model by combining the Individual Impact and Organizational Impact variables into a single dimension called Net Benefits, and they added a new dimension called Service Quality. The result is a comprehensive model that can be applied to assess the success of information systems in the Internet environments. The model retained the basic premise of its original model, which states that the success of information systems should be verified by interdependent multidimensions, as illustrated in Figure: 1.

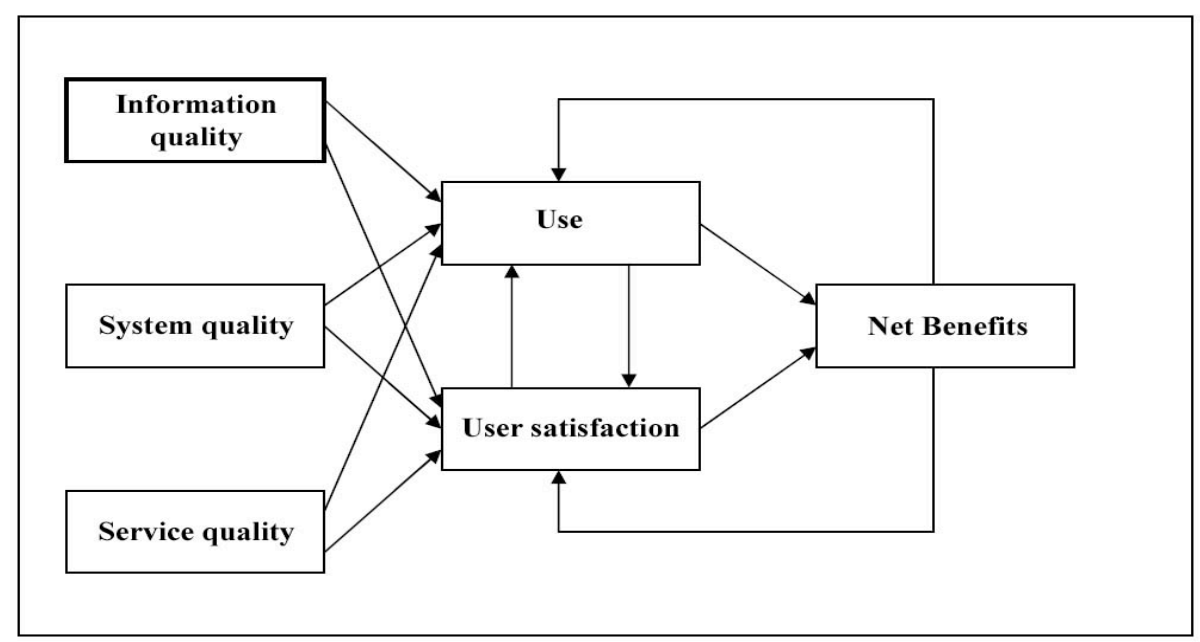

Figure: 1

Updated Information Systems Success Model (DELONE and MCLEAN, 2003).

Just like its predecessor, the new model utilizes recursive and non-recursive causal relationships. Non-recursive relationships make use of reciprocal feedback when two variables are simultaneously dependent on and independent from one another. User Satisfaction has a cyclical relationship with Use. Such feedback relationships were explored in several studies, the findings of which support the model (Delone and McLean, 2003; WI and Wang, 2006). However, an analysis of the non-recursive relationship between Use and Net Benefits is a subject of debate in among the scientific community. 
Although some researchers believe the relationship must be only temporal and not causal (SEDDON, 1997), others believe that it is possible to proceed with a reciprocal causality analysis using instrumental variables (Martens and Haase, 2006). Such discussions must be taken to greater depth, and researchers must clearly define the assumptions of the analysis when using the present model.

System Quality refers to aspects of the information system itself, such as processing speed, ease of use, necessary requirements, and navigability. These are important factors that are the responsibility of the technical team, from the inception of the system to its planning and implementation. Twelve works by Delone and Mclean (1992) employed the following measures on a frequent basis: response time, system reliability, and especially, ease of use.

Information Quality refers to the quality of the content stored in the system. In this case, it includes factors such as the quality of graphs and data, and the clarity with which the information is presented to users. Delone and Mclean (1992) created thirty factors related to this dimension, including importance, reliability, relevance, currency, clearness, legibility, and interpretability. A significant majority of these are measured from the user's viewpoint.

Service Quality is essential to implement the information system, as some essential services are fundamental, such as user training, a help desk, and support. The quality of the services depends on the performance of those who provide them at the moment they are delivered. Services can be offered either through the information system itself or offline.

User Satisfaction refers to the extent to which the user is satisfied with the system, information, and service. The user's perception of and attitude toward the environment as a whole reflects the concept of user satisfaction.

Use refers to a measure of how much and which resources are used. This construct is visible only when the use of resources is not imposed, that is, to measure use accurately, access must be voluntary. Delone and Mclean (1992) indicated distinct ways of measuring use, including the number of times the system is accessed, length of access time, access to distinct resources, and access to optional resources.

Net Benefits refers to the main benefits derived from increased use and user satisfaction when interacting with the information system. This construct is flexible and depends exclusively on the system objectives, which can be cost reduction, personal satisfaction, professional outcomes, and increased profitability.

Success Assessment of Distance-Learning Systems

The development of a good virtual learning environment has various advantages, including personalization, omnipresence, interactions, and ease of use (Ozkan and Köseler, 2009; Sitzmann, 2006). However, success depends on the proper development, implementation, and continuous assessment of the distance-learning platform because only a well-conceived virtual learning environment will produce good results (Dennis, Wixom and Roth, 2006; Kavanagh and Thite, 2009; Sommerville, 2007). 
A major issue is how to identify the quality of the virtual learning environment and the factors related to the success of its implementation. In order to find plausible solutions for the e-learning assessment process, concepts related to information systems assessment were widely used (Delone and Mclean, 1992; Davis, 1993; Venkatesh and Bala, 2008; Van Aken, 2005).

Later, studies such as those by Holsapple and Lee-Post (2006) applied several scientific theories and adapted them to distance learning. Of all the theories on IT success that were applied to e-learning, two have been the most influential worldwide: the Information Systems Success Model (ISSM) by Delone and Mclean (2003), and the Technology Acceptance Model (TAM) by Davis (1989). A study carried out by Mueller and Strohmeier (2011) analyzed the research on e-learning evaluation in terms of design characteristics and the theories utilized.

Thirty relevant studies were evaluated. Ten used the Delone and Mclean model (2003), 22 applied the TAM model (Davis, 1989), and 10 studies employed other theories. It is apparent that there has been an effort to identify the important factors contributing to elearning success.

Several aspects must be evaluated when one is engaged in distance learning, including quality of the information technology, quality of the course content, and quality of the services rendered by the institution and channeled by technology.

Authors like Holsapple and Lee-Post (2006), liaw and Huang (2003), Liaw (2006), Lin (2007), Mueller and Zimmermann (2009), Poelmans (2008), Roca, Chiu, and Martinez (2006), Wang and Wang (2009), Wang (2007), and Yeung and Jordan (2007) have used the information systems success model (Delone and Mclean, 2003) as the theoretical basis for evaluating the quality of distance-learning platforms.

The conceptual basis states that net benefits are achieved by the use of the system and user satisfaction. These, in turn, are impacted by system quality, information quality, and service quality (Liaw and Huang, 2003), which create a complete model that anticipates the success of implementing e-learning actions.

\section{E-Learning Success Assessment Model by Holsapple and Lee-Post (2006)}

Based on the Delone and Mclean (2003) Information Systems Success Model, Holsapple and Lee-Post (2006) developed a study in which the model was adapted and applied to the e-learning. Their E-Learning Success Model (Figure 2) has a structure based on Delone and McLean (2003), and it proposes that the global success of e-learning depends on the success of three stages: design, delivery, and outcome. The delivery stage is evaluated along two dimensions: use and user satisfaction.

Use is related to the intensity with which the student is accustomed to using the system and which resource was accessed. Satisfaction refers to the feeling that it was worthwhile to have participated in this distance course or event.

The third stage of the model is evaluated with respect to the net benefits received by the user, such as the impact on learning or professional success and other factors. 


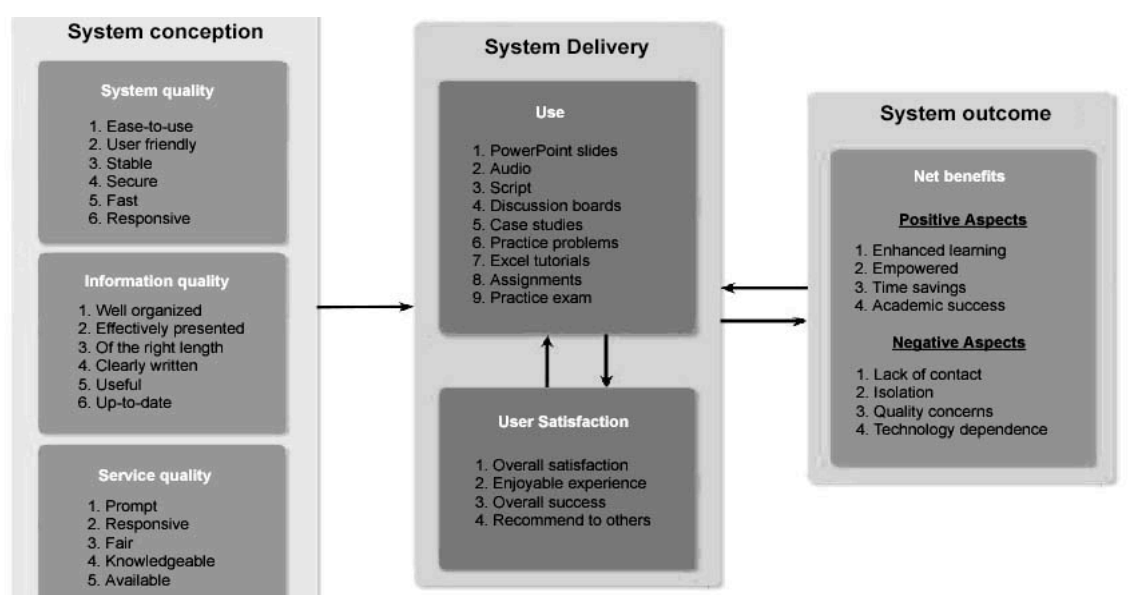

Figure: 2

\section{METHOD}

E-Learning Success Model and Metrics Examples

The social sciences are rich in the utilization of various methods, and this occurs because humankind is a major object of study in this scientific field. There is a clear need to use not just one single analysis approach, but diversified and comprehensive investigations that enhance the comprehension of human complexity (Demo, 1995). The proposed elearning success assessment was designed by using multiple research and quantitative methods (Holsapple And Lee-Post, 2006). The goal, to identify the associations among elearning-success dimensions and to confirm whether the model is valid through a quantitative approach, was proposed by the authors.

In accordance with Demo (1995, p. 133), "In quantitative terms, the social sciences already have a satisfactory empirical research 'luggage' and regardless of the existing vices, limitations, as well as mystifications, it is a product of particular methodological meaning." In order to achieve the objectives of this study, a quantitative survey method was selected.

The survey method can be described as the acquisition of data on characteristics, actions, or opinions of a certain group of individuals who represent the target population by means of a research instrument, usually a questionnaire (Pinsonneault and Kramer, 1993). For Fink (1995a, 1995b), the interest of a survey is to produce quantitative descriptions of a population. This was an explanatory cross-sectional study intended to test part of the theoretical model proposed by HOLSAPPLE and Lee-Post (2006), having a non probabilistic subset of students from five regions of Brazil as sample. For Pinsonneault and Kraemmer (1993), the objective of an explanatory survey is to test a theory, to establish the existence of causal relationships, and to question why such relationships exist.

\section{Sample, Data Collection, and Procedures}

A survey was conducted with 291 students enrolled in public and private institutions from five Brazilian regions. An online program named "Interview and Selection Techniques" was designed and offered by email and social networks to the students. An online survey was available for $\mathbf{3 0}$ days on a website on a proprietary domain. 
This first survey identified the students' enrollment intentions in addition to characterizing the study sample on four dimensions:

$>$ student identification;

$>$ expertise with computers, the Internet, and online course programs;

$>$ impressions of e-learning; and

$>$ readiness/willingness to participate in distance learning courses.

The dimensions measured in this survey were based on previous studies on distance learning (Holsapple and Lee-Post, 2006; Mason and Rennie, 2006; Rosenberg, 2001). During the 30-day pre-enrollment period, the pre-enrollment page had 6,398 visits, and 2,236 enrollments were confirmed, equivalent to $35 \%$ of the visitors. To acquire a sample for pre-testing, 198 students were asked to respond to a questionnaire one week before the end of the program. The pre-test was conducted to identify problems with the clarity or reliability of the questionnaire, and the instrument was then refined by deleting or changing some of the questions in the final version.

At the end of the fourth week of the program, 320 students had responded to the revised questionnaire. A thorough analysis of the structural equation interactions eliminated 29 multivariate outliers, leaving 291 records in the final sample.

\section{Sample Characteristics}

The sample consisted of 291 Brazilian students who participated in an online program called "Interview and Selection Techniques" from April to May 2012 after enrolling at the specific site. Pre-enrollment allowed access to the survey, which was filtered only for the final participants. Two hundred of the students were women $(68.7 \%)$, and 91 were men $(31.3 \%) ; 137(47 \%)$ were students from public institutions and $154(53 \%)$ were from private institutions. On average, they accessed the Internet six days a week. Mean age was 27.05 years, with a standard deviation of 8.34. On a scale from 1 to 7 , the average rating of computer skills was 5.63 .

With respect to the geographical location of the sample, five regions of Brazil participated in the survey. The highest number of participants was from the Northeastern region, with 133 individuals $(45.7 \%)$ from eight of the nine Northeastern states, followed by the Southeastern region with 108 individuals (37.1\%) from all four states. Thirty-five individuals $(12 \%)$ represented four of the seven states of the Northern region. The Southern and Mid-Western regions had 11 (3.8\%) and four (1.4\%) participants, respectively.With regard to educational level, $44.3 \%$ of participants had completed undergraduate programs, $28.9 \%$ secondary school, $12 \%$ specialization course programs, $12 \%$ technical schools, $2.4 \%$ elementary school, and $0.3 \%$ master's programs; $47.5 \%$ of the women had completed undergraduate programs, compared to $37.4 \%$ of the men. With regard to specialization, $13.5 \%$ of the women were specialists, and only $8.8 \%$ of the men had already completed a "latu-sensu" graduation school. Of the women, $61 \%$ had earned a graduate degree compared to $47.3 \%$ of the men. In view of the disproportionate distribution of gender in the sample (91 men and 200 women), a vertical analysis of the sample (schooling) was not performed. Of the 291 survey respondents, 176 individuals $(60.48 \%)$ had never studied via Internet, and 218 individuals (74.19\%) were not knowledgeable about the virtual learning environment used in the program (Moodle). 
When asked why they had never taken a course via Internet, $53 \%$ said they never found any course of interest; $\mathbf{4 1 \%}$ stated they were afraid of not learning the same way they would in a traditional, face-to-face class setting, and $38 \%$ believed that human contact, the ability to see the teacher and classmates, is more productive and pleasant. Also $\mathbf{7 4 . 5 9 \%}$ of the students mentioned time flexibility and comfort of studying at home, at work, or anywhere (52.64\%), and the possibility of harmonizing work and study $(32.58 \%)$. With regard to the types of courses the students would be interested in taking the majority $(\mathbf{7 7 . 9 8 \% )}$ would take short-term non-credit courses. Vocational training courses $(47.13 \%)$ and medium-term extension courses $(38.84 \%)$ also made the top of the list. Undergraduate and specialization courses were mentioned by $17.35 \%$ and $\mathbf{2 7 . 3 0 \%}$, respectively. About the preferred mode of instruction between distance-learning course and a traditional course in a face-to-face class setting, with a warranty of quality being offered, learning/knowledge to be acquired, and the price as similar in both courses on the same subject, most students said they would choose to take a traditional class $\mathbf{( 5 8 . 6 0 \% )}$. This indicates that a parcel of Brazilian students is still resistant to the online mode of educational activity.

\section{Data Treatment and Analysis}

Structural Equation Modeling (SEM) techniques were employed for data treatment and analysis and simultaneously examines a series of dependence relationships. This method is useful when a dependent variable becomes independent in ensuing dependence relationships (HAIR et al., 1998), which may turn out to be a significant advantage with regard to other multivariate techniques. Also enables the researcher to study how well the predicting variables (independent/exogenous) explain the dependent variable (endogenous), and which of the predicting variables is the most important one. Although this is also possible with the use of regression, SEM is the more advantageous method because it allows for more than one dependent variable in the same model (Maruyama et al., 1998; apud. Farias And Santos, 2000). Another advantage of using SEM is that it is possible to carry out an estimate of the parameters' errors with this method, whereas some techniques, such as those of general linear models, do not provide the exploratory variable errors (Lemke, 2005). The software packages selected for data analysis were the Statistical Package for the Social Sciences (SPSS) and Analysis of Moment Structures (AMOS), both provided by IBM.

The existence of outliers was evaluated by Mahalanobis square distance $\left(\mathrm{DM}^{2}\right)$, and normalcy was evaluated by the asymmetry coefficients (Sk), and univariate and multivariate kurtosis (Ku). No variable showed Sk and $\mathrm{Ku}$ amounts greater than the 3 (Sk) and 10 (Ku) limits, as identified by MARÔcO (2010). Even though the KolmogorovSmirnov and Shapiro-Wilk tests have shown significant statistical significance in the normalcy of the breakdowns, the absence of severe infringement to the normal breakdown shown in the kurtosis and asymmetry tests enables one to continue performing the analysis (Maroco, 2010). In this study, the highest amount of asymmetry was 2.12, while that of kurtosis was 3.82. Twenty-nine observations yielded high DM2 amounts, which indicate the possibility of there being multivariate outliers.

Thus, factorial analysis was performed without these observations. With regard to the assumption of the absence of multicollinearity, variance inflation factor (VIF) tests were performed on SPSS through multiple linear regression, using the "Use" factor score as a dependent variable. No variable exceeded the $\mathrm{VIF}=10$ as pointed out by MarocoA (2010). 
The following constructs were analyzed: System Quality (Top VIF= 2.96), Information Quality (Top VIF=1.79), Service Quality (Top VIF=2.31), Use (Top VIF=1.55), and User Satisfaction (Top VIF=1.81). The absence of collinearity among the independent variables may also be confirmed in the correlation matrix (Figure: 4).

\begin{tabular}{l|rrrrrrrrrrrrrrr} 
& SU3 & SU2 & SU1 & US3 & US2 & US1 & QSE2 & QSE5 & QSE6 & QI1 & QI4 & QI5 & QS1 & QS3 & QS4 \\
\hline SU3 & 1,000 & & & & & & & & & & & & & & \\
SU2 &, 518 & 1,000 & & & & & & & & & & & & & \\
SU1 &, 625 &, 494 & 1,000 & & & & & & & & & & & & \\
US3 &, 431 &, 543 &, 437 & 1,000 & & & & & & & & & & & \\
US2 &, 358 &, 381 &, 373 &, 492 & 1,000 & & & & & & & & & & \\
US1 &, 441 &, 393 &, 435 &, 485 &, 534 & 1,000 & & & & & & & & & \\
QSE2 &, 453 &, 549 &, 447 &, 446 &, 381 &, 406 & 1,000 & & & & & & & & \\
QSE5 &, 476 &, 531 &, 454 &, 392 &, 341 &, 420 &, 684 & 1,000 & & & & & & & \\
QSE6 &, 482 &, 470 &, 374 &, 299 &, 342 &, 332 &, 680 &, 697 & 1,000 & & & & & & \\
QI1 &, 388 &, 403 &, 426 &, 286 &, 337 &, 296 &, 401 &, 399 &, 305 & 1,000 & & & & & \\
QI4 &, 386 &, 437 &, 380 &, 404 &, 351 &, 310 &, 369 &, 312 &, 254 &, 455 & 1,000 & & & & \\
QI5 &, 512 &, 584 &, 580 &, 525 &, 455 &, 381 &, 393 &, 385 &, 361 &, 577 &, 559 & 1,000 & & & \\
QS1 &, 242 &, 230 &, 296 &, 231 &, 200 &, 244 &, 232 &, 163 &, 172 &, 202 &, 280 &, 303 & 1,000 & & \\
QS3 &, 232 &, 329 &, 267 &, 294 &, 326 &, 297 &, 308 &, 216 &, 246 &, 285 &, 284 &, 310 &, 665 & 1,000 & \\
QS4 &, 210 &, 295 &, 259 &, 311 &, 278 &, 268 &, 295 &, 161 &, 210 &, 203 &, 275 &, 275 &, 729 &, 756 & 1,000
\end{tabular}

Figure: 4

Correlation Matrix

\section{RESULTS AND DISCUSSION}

In order to estimate the model's fit to the data, the maximum verisimilitude method and structural equation modeling techniques were employed as statistical analysis tools. The model was evaluated in two steps.

First, the two measuring models (independent and dependent) were analyzed for dimensionality, validity, and reliability by employing confirmatory factor analysis.

Next, the causal relationships proposed in the assumptions were evaluated through the structural equations' coefficient path analysis and the global fit indexes described by KLINE (1998) and MARÔCO (2010).

The compound reliability test was performed as indicated by Fornell and Lacker (1981). In order to validate each construct indicators' convergence, the Average Variance Extracted-AVE (Fornell and Lacker, 1981) was employed. Discriminatory validity was evaluated by putting together all possible pairs of constructs and comparing the models in which the correlation among the constructs is free as opposed to a model in which the correlation equals 1.0. In order to refine the model, modification indexes (IM) were employed. It was considered that IM $>11(p<0.001)$ indicated local fit problems.

The significance of the structural coefficients was evaluated with a t-test produced by the AMOS software package (critical ratio and p-value), considering as statistically significant the estimates of the parameters with $p<0.05$. Table: 1 show the fit indexes for the three models, which shall be discussed in the subsequent sections. 
Table: 1

Fit index for the measurement and structural indexes

\begin{tabular}{|c|c|c|c|c|}
\hline FIT INDEXES & $\begin{array}{l}\text { MEASUREMENT } \\
\text { MODEL FOR } \\
\text { ANTECEDENTS }\end{array}$ & $\begin{array}{c}\text { MEASUREMENT } \\
\text { MODEL FOR } \\
\text { DEPENDENTS }\end{array}$ & $\begin{array}{l}\text { STRUCTURAL } \\
\text { MODEL }\end{array}$ & $\begin{array}{l}\text { RECOMMENDED } \\
\text { VALUES }\end{array}$ \\
\hline $\begin{array}{l}\mathrm{X}^{2} / \mathrm{df} \text { (chi-square } \\
/ \text { degrees of freedom) }\end{array}$ & $\begin{array}{c}36.29 / 24= \\
1.51\end{array}$ & $\begin{array}{c}27.873 / 8= \\
3.484\end{array}$ & $\begin{array}{c}161.967 / 81= \\
2.000\end{array}$ & $\begin{array}{c}<5.00 \\
\text { (MARÔCO, 2010) }\end{array}$ \\
\hline p-value & 0.051 & 0.000 & 0.000 & $\begin{array}{c}>0.05 \\
\text { (KLINE, 2005) }\end{array}$ \\
\hline $\begin{array}{l}\text { Root Mean Square } \\
\text { Error (RMSEA) }\end{array}$ & 0.042 & 0.093 & 0.059 & $\begin{array}{c}<0.10 \\
\text { (MARÔCO, 2010) }\end{array}$ \\
\hline $\begin{array}{l}\text { RMSEA Lower } \\
\text { Limit (LO 90) }\end{array}$ & 0.000 & 0.057 & 0.045 & $\begin{array}{c}<0.05 \\
(\text { KLINE, 2005) }\end{array}$ \\
\hline $\begin{array}{l}\text { RMSEA Upper } \\
\text { Limit (HI 90) }\end{array}$ & 0.068 & 0.131 & 0.072 & $\begin{array}{c}<0.10 \\
\text { (KLINE, 2005) }\end{array}$ \\
\hline $\begin{array}{l}\text { Comparative Fit } \\
\text { Index (CFI) }\end{array}$ & 0.990 & 0.967 & 0.963 & $\begin{array}{c}>0.80 \\
(\text { MARÔCO, 2010) }\end{array}$ \\
\hline $\begin{array}{l}\text { Incremental } \\
\text { Fit Index (IFI) }\end{array}$ & 0.990 & 0.967 & 0.964 & $\begin{array}{c}>0.90 \\
\text { (KLINE, 2005) }\end{array}$ \\
\hline $\begin{array}{l}\text { Normed Fit } \\
\text { Index (NFI) }\end{array}$ & 0.972 & 0.955 & 0.930 & Closer to 1 \\
\hline $\begin{array}{l}\text { Root Mean Square } \\
\text { Residual (RMR) }\end{array}$ & 0.010 & 0.011 & 0.011 & $\begin{array}{c}<0.05 \\
(\text { KLINE, 2005) }\end{array}$ \\
\hline $\begin{array}{l}\text { Goodness-of- } \\
\text { Fit Index (GFI) }\end{array}$ & 0.973 & 0.969 & 0.932 & $\begin{array}{c}>0.80 \\
\text { (MARÔCO, 2010) }\end{array}$ \\
\hline $\begin{array}{l}\text { Adjusted } \\
\text { Goodness-of-Fit } \\
\text { Index (AGFI) }\end{array}$ & 0.949 & 0.918 & 0.900 & $\begin{array}{c}>0.80 \\
(\text { MARÔCO, 2010) }\end{array}$ \\
\hline
\end{tabular}

Remarks: The recommended values comply with KLINE'S (2005) and MARÔCO'S (2010) indications. There are no recommended amounts for NFI. Values nearest to 1 indicate the best fit.

\section{Measurement Model-Independent Variables}

The antecedents model resulted in a very good fit with 24 degrees of freedom and a nonsignificant chi-square $=36.29(p>0.05)$ and RMSEA $=0.042(0.000$ and 0.068 limits for $90 \%$ IC). Other indexes corroborate the model's good fit, such as CFI (0.99), IFI (0.99), NFI (0.972), RMR (0.01), and GFI (0.973).

Analyzing the residual matrices, no troublesome stress points were identified. Modification indexes exceeding $11(p=0.001)$ were also not identified. With regard to the indexes' factorial loads, all were positive and significant $(p<0.001)$.

The compound reliability test showed results in excess of the value indicated by FORNELL and LACKER (1981) i.e., 0.70. The following constructs were analyzed: System Quality (0.89), Information Quality (0.78), and Service Quality (0.87).

With regard to convergent validity represented by the mean variances extracted, it was plausible, with values in excess of 0.50 (0.72 for System Quality, 0.54 for Information Quality, and 0.69 for Service Quality). 
On the chi-square tests, all pairs of constructs indicated significant $p$-values $(p<0.001)$. A significant value for the chi-square statistical difference for the two nested models indicated that the constructs were different and ensured discriminatory validity ( $O$ 'LearyKelly and Vokurka, 1998; Bagozzi, Yi, and Phillips, 1991).

Reliability, convergent validity, and discriminatory validity were adequate. Thus, the antecedent measurement method was valid and reliable, ensuring that the scales properly represent the underlying constructs.

\section{Measurement Model-Dependent Variables}

The dependent variables measurement model comprises the Use and User Satisfaction constructs. The model's fit was considered poor according to the following indexes: RMSEA equal to 0.09 and $X^{2}$ /degrees of freedom equal to 3.484 .

Nevertheless, since the factorial loads showed relatively high values $(>0.7)$, there were no serious indications of modifications, and the remaining fit indices were excellent; a decision was made to go ahead with the analysis with no changes. In spite of the poor fit indicated by the chi-square indexes, other indicators showed that it is possible to use the model. This statement can be corroborated by the following results: CFI (0.967), RMR $(0.01)$, NFI (0.95), and GFI (0.96). Both constructs were deemed reliable, as evidenced by the compound reliability indexes of the Satisfaction $(0.79)$ and Use $(0.75)$ constructs.

With regard to the convergent validity, the variables passed the average variance explained (AVE) tests and resulted in indices 0.55 and 0.50 for Satisfaction and Use, respectively. The difference in chi-square between the construct pairs with a free correlation and with a fixed correlation was evaluated.

The result showed a significant $p$-value that is equal to 0.000 , ensuring that the underlying variables are distinct. One can state that the dependent variable measurement to be employed in the structural model is reliable and valid.

\section{Structural Model}

After checking the reliability and validity of the constructs of the two measurement models (antecedents and dependents), the structural model, in which both measurement models were run simultaneously, was analyzed. Small changes in factorial loads of the indicators of the various underlying values were identified; the quality of the analysis was not affected.

The standardized path coefficients can be seen in Figure: 5 . The estimates are standardized and the significance of the relationships can be seen in Table: 1.

The structural model of antecedents of both Satisfaction and Use in virtual learning environments showed good fit and plausible path coefficients.

All p-values were significant except for the association between System Quality and Satisfaction relationship, which was not significant $(0.608)$.

It was possible to identify 0.66 and 0.89 explained variance for the constructs Use and Satisfaction, respectively. 
Frame: 1

Regression Weights: Structural Models of Antecedents of Satisfaction and Use Values in Distance learning

\begin{tabular}{|c|c|c|c|c|c|c|}
\hline & & & Estimate & SD & $\begin{array}{c}\text { Critical } \\
\text { Value }\end{array}$ & p-Value \\
\hline Use & $<--$ & SystemQ & .116 & .049 & 2.350 & .019 \\
\hline Satisfaction & $<---$ & SystemQ & .021 & .040 & .514 & .608 \\
\hline Use & $<---$ & InformQ & .530 & .088 & 6.040 & $* * *$ \\
\hline Satisfaction & $<---$ & InformQ & .628 & .080 & 7.890 & $* * *$ \\
\hline Use & $<---$ & ServQ & .246 & .062 & 3.973 & $* * *$ \\
\hline Satisfaction & $<---$ & ServQ & .326 & .051 & 6.353 & $* * *$ \\
\hline
\end{tabular}

Source: Amos Software

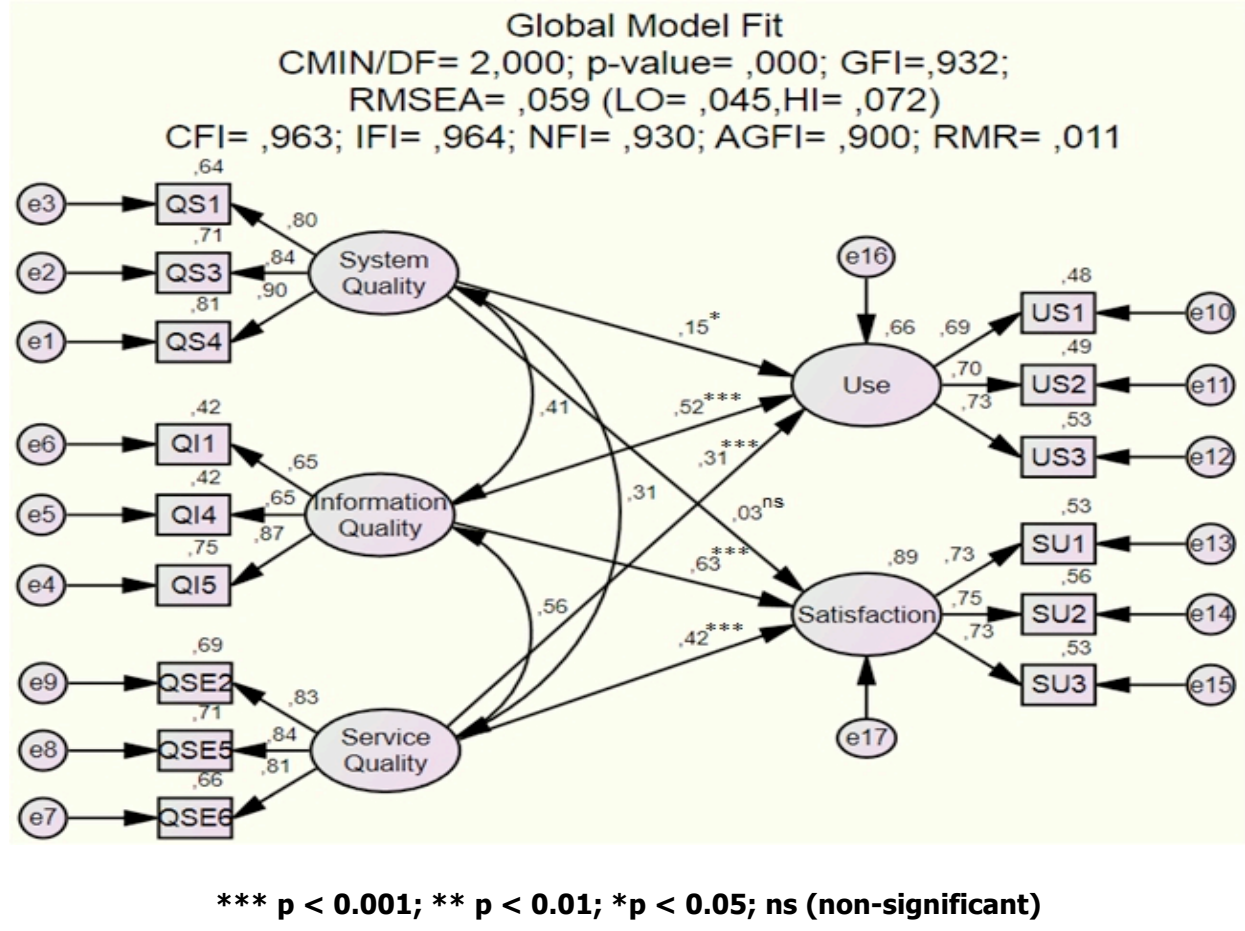

Figure: 5

Structural Model of the Antecedents of Satisfaction and Use in Distance learning

After the evaluation process of the final structural model, one can conclude that the hypothetical model of the antecedents of Satisfaction and Use in virtual learning environments properly represented the population that was surveyed, as evidenced by the following factors.All the model constructs passed the reliability and validity tests; The measurement models of antecedents and dependents showed a good fit; Plausibility and statistical significance of almost all of the estimated parameters; The structural model showed good fit, especially with regard to the following values: RMSEA (0.059), CFI $(0.963)$, and GFI (0.932); The high explained variance of the following dependent constructs: Use and Satisfaction ( 0.66 and 0.89 , respectively). 
Interested in identifying the most important variables that compose the complex success model in distance learning. authors, like Holsapple and Lee-Post (2006), have disclosed that the net benefits of distance learning are brought about by an increase in students' use of and satisfaction with the virtual learning environment. This paper analyzed the role of the following variables: System Quality, Information Quality, and Service Quality as antecedents of Satisfaction and Use of systems in distance learning. The results corroborate almost all propositions published in the literature on informationtechnology-services evaluation and e-learning evaluation, which state that the system, information, and service bring about satisfaction and use in IT (Delone and McLean, 2003; Ozkan And Koseler, 2009; Shee And Wang, 2008).

\section{H1: System quality positively influences USE,}

and H2: System quality positively affects User Satisfaction

The results of this survey corroborate assumption 1 . The association of the perception of system quality on the use of the distance-learning system was tested with structural equations based on a co-variance matrix. With a significance level of 0.019 and a path coefficient that is equal to $\mathbf{0 . 1 5}$, one can say that the increase in use is affected by the user's perception of the system quality. It is worth pointing out that the indicators of the underlying variable System Quality are associated with availability and ease of use of the technical and visual resources. People engaged in distance learning must strive to design systems that are clear, pleasant, and, especially, user-friendly because their use is associated with these characteristics.

But no statistically significant data was found that would corroborate assumption 2 . With a path coefficient equal to 0.03 and a p-value equal to 0.608 , there are indications that the perception of the system quality does not directly affect user satisfaction. If students perceive that a system has good quality, there is still no guarantee that they will be satisfied with the program. This result is in keeping with the Holsapple and Lee-Post (2006) theoretical model. It is possible to conclude that the construct System Quality has a low influence on the Use variable and no predictive power with regard to Satisfaction, which weakened the construct in this model. System Quality is just a complement for the remaining factors in distance learning. Students did not report direct satisfaction just because they liked the system that managed the program. Rather, they report satisfaction after identifying other values in connection with content and services.

H3: Information Quality is positively associated with Use, and H4: Information Quality is also positively associated with User Satisfaction

Aspects related to the program content, such as text clarity, quality, and relevance of materials, were measured within the concept of Information Quality.

The study of antecedents of Satisfaction and Use in distance learning corroborates assumption 3; the better the information quality is perceived, the more the system is used. Tests indicate a path coefficient equal to 0.52 , with a good level of statistical

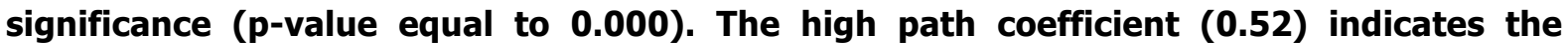
extent to which the construct Information Quality has causality power over the construct Use. Students intensify their use of a system when they perceive meaning in clear, wellwritten, and relevant content. The results of this study also confirm the causal relationship Information Quality on User Satisfaction. The high path coefficient for the model $(0.63)$ indicates that distance-learning students tend to be much more satisfied with a program when they perceive high-quality information. 
H5: Service Quality is positively associated with Use, and H6: Service Quality positively associated with User Satisfaction

Confirmed assumption 5 . The students' perception of service quality had an effect on increased use of the system (path coefficient $=0.31 ; p=0.000$ ). People must invest in software and processes that create a close relationship among students, tutors, teachers, and technical crew by means of the best interaction possible. The use of asynchronous and synchronous activities, especially the latter, in addition to a process structure that enables students to obtain responses with regard to technical or academic requirements quickly, may have a direct impact on the increased intensity of use. Statistical significance was also found in the following relationship: Service Quality on User Satisfaction (path coefficient $=0.42 ; p=0.000$ ), which confirms assumption 6 (Service Quality positively affects the User Satisfaction).

One of the goals of the structural equation hypothetical model is to identify the extent to which independent variables are able to explain the variance of the dependent constructs. Here, there are two underlying dependent variables, Use and User Satisfaction, which were subjected to tests to verify the extent to which they are predicted by the variables System Quality, Information Quality, and Service Quality. The Use construct had a $66 \%$ explained variance, which is considered a good result. Over half of the explanatory factors of the Use construct were identified in this study. The three antecedent variables were part of the breakdown of the explained variance of the Use construct, and Information Quality was the most important construct (path coefficient = 0.52). Other variables that are not predicted in the model may be the object of a future study. Nevertheless, the current study is a contribution to distance learning in Brazil.

The User Satisfaction construct had $\mathbf{8 9} \%$ of variance explained by Information Quality and Service Quality. The current study made a significant contribution to the understanding of the factors that affect virtual students' satisfaction. This work is an achievement that will enable managers, teachers, and distance-learning teams to make the best decisions. The Information Quality construct showed the highest predictive power in the model, followed by Service Quality. System Quality was the weakest independent variable in the structural model.

\section{CONCLUSIONS, OPPORTUNITIES, AND LIMITATIONS}

With the growth of distance learning, institutions are seeking to improve this instructional mode and reduce the dropout rate caused by a number of factors, among which is students' dissatisfaction. Previous studies on e-learning indicate that student satisfaction with and use of the system generate net benefits of distance learning in addition to playing a major role in student retention and maintenance, thus reducing the dropout rate.

This study evaluated the antecedents of student satisfaction and use of systems in a virtual learning environment and showed the degree of importance of the dependent variables. The results indicate that Information Quality had a greater impact on Satisfaction and Use, followed by Service Quality and System Quality.

One can state that students' degree of satisfaction and use of a system will be greater when they perceive higher information quality, whereas System Quality had the weakest power of causality within the model. 
When making investment decisions, managers having this awareness can evaluate the dimensions that warrant attention, thus generating intelligent solutions that create a quality distance-learning structure.

In an effort to find links to other dimensions of the Satisfaction and System Use constructs, future studies may propose new approaches to the model to examine issues such as the dropout rate, net benefits, and students' intention to continue with a distance-learning program.

A limitation of this study is the possible impact of using a 5-point Likert scale. Nevertheless, the model's adjustment indices were not greatly affected. In addition, good results can be obtained when one uses Likert-type scales with at least five categories (Hancock and Mueller, 2006).

Another limitation of the study was the non-probabilistic sampling generated by spontaneous enrolling of individuals from Brazil's five regions.

\section{BIODATA and CONTACT ADDRESSES or the AUTHORS}

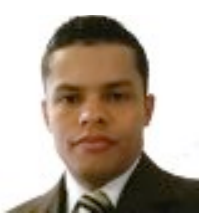

F. N. MACHADO-DA-SILVA is a PhD Student in Business Administration from the São Paulo Business School in Fundação Getulio Vargas-EAESP/FGV. He is a Federal Public Service and researcher in applied social sciences, specializing in Multivariate Data Analysis.

F. N. MACHADO-DA-SILVA

Av. Mogi das Cruzes, 1501-Suzano-São Paulo-BRAZIL

Instituto Federal de São Paulo (IFSP), BRAZIL

Fundação Getulio Vargas (EAESP/FGV), BRAZIL

Phone:+5511 98473-2324

Email: fabio@machado.adm.br

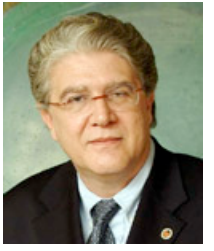

F. S. MEIRELLES Engineering at IMT-EEM in 1972. After the Masters (MSc, Engineering Management) from Stanford University in 1977. Doctor of Business Administration from FGV-EAESP. Participated in several graduate programs at Harvard Business School, MIT-Massachusetts Institute of Technology and the University of Texas at Austin. 30 years of experience as a professor, executive and consultant.

He has been a full professor at Escola de Administração de Empresas de São Paulo (Sao Paulo Business School) at Fundação Getulio Vargas-FGV-EAESP. He participated in all programs delivered at the School (Undergraduation, Graduation, Specialization, MBA, GVconsult, GVpec and GVnet).

\section{F. S. MEIRELLES}

Av. Nove de Julho, 2029 - São Paulo - SP, BRAZIL

Fundação Getulio Vargas (EAESP/FGV), BRAZIL

Phone: +5511 3799-7777

Email: fernando.meirelles@fgv.br 


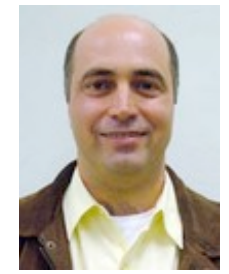

Douglas FILENGA is a PhD Student in Business Administration from the São Paulo Business School in Fundação Getulio Vargas - EAESP / FGV. He investigates absorptive capacity, knowledge management / information, organizational commitment and justice. He is a professor and researcher at the Methodist University of São Paulo. Also is a Reviewer of articles for scientific journals and congresses.

\section{Douglas FILENGA}

Travessa Oscar Freire, 30 Vila Scarpelli-Santo André;

São Paulo; Brasil, BRAZIL

Fundação Getulio Vargas (EAESP/FGV), BRAZIL

Universidade Metodista de São Paulo

Phone(s): +5511 44265619 or 9-96830296

Email: filenga@gmail.com or Douglas.filenga@metodista.br

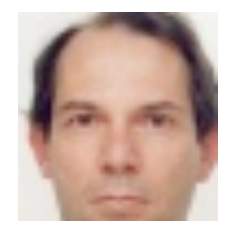

Marino Brugnolo FILHO is a PhD Student in Business Administration from the São Paulo Business School in Fundação Getulio Vargas-EAESP/FGV. He is a business consultant and acts as a professor at Guarulhos University in São Paulo.

\section{Marino Brugnolo FILHO}

Av. Pavão, 231. Apto 31a-São Paulo-SP, BRAZIL

Fundação Getulio Vargas (EAESP/FGV), BRAZIL

Phone: +5511 2461-3187 or $99610-0119$

Email: marino.brugnolo@gmail.com

\section{REFERENCES}

Byrne, R. (2002). Web-based learning versus traditional management development methods. Singapore Management Review, v. 24, n. 2, p. 59-68.

Davis, F. D. (1993). User acceptance of information technology: system characteristics, user perception and behavioral impact. International Journal of Man-Machine-Studies, $v$. 38 , n. 3, p. 475-487.

Delone, W. H. and McLean, E. R. (1992). Information systems success: The quest for the dependent variable. Information Systems Research, v. 3, n. 1, p. 60-86.

Delone, W. H. and McLean, E. R. (2003). The DeLone and McLean model of information systems success: A ten-year update. Journal of Management Information Systems, v. 19, n. 4, p. 9-30.

Demo, P. (1995). Metodologia Científica em Ciências Sociais. São Paulo: Atlas.

Dennis, A. R., Wixom, B. H., and Roth, R. M. (2006). Systems analysis and design. Hoboken: John Wiley \& Sons. 
Farias, S. A and Santos, R. C. (2000). Modelagem de Equações Estruturais. RAC, v. 4, n. 3, p. 107-132.

Fink, A. (1995a). How to design surveys. The Survey ed. Thousand Oaks: Sage.

FINK, A. (1995b). The survey handbook. The Survey ed. Thousand Oaks: Sage.

Fornell, C. and Larcker, D. F. (1981). Evaluating structural equation models with unobservable variables and measurement error. Journal of Marketing Research, v. 18, p. 39-50.

Hair, J. F. et al. (1998). Multivariate data analysis. 5. ed. New Jersey: Prentice Hall.

Hancock, G. R. and Mueller, R. O. (2006). Structural equation modeling: A second course. Greenwich, CT: Information Age Publishing.

Holsapple, C. W. and Lee-Post, A. (2006). Defining, assessing, and promoting e-learning success: An information systems perspective. Decision Sciences Journal of Innovative Education, v. 4, No, p. 18.

Jewett, F. (1998). Case studies in evaluating the benefits and costs of mediated and distributed leaning. In: Proceedings Of The 3rd Annual Conference of The Telelearning Network Of Centers of Excellence. Annals. Vancouver, Canada.

Jing, I. et al. (2002). Effects of different types of interaction on learning achievement, satisfaction and participation in web-based instruction. Innovations in Education and Teaching International, v. 39(2), p. 153-162.

Kavanagh, M. J. and Thite, M. (2009). Human resource information systems: basics, applications, and future directions. Los Angeles: Sage.

Kelly, P. (2011). Web 2.0-based e-learning: Applying social informatics for tertiary teaching. Open Learning, v. 26, n. 3, p. 280-283.

Kline, R. B. (1998). Principles and practice of structural equation modeling. New York: The Guilford Press.

Lawhead, P. B. et al. (1997). The Web and distance learning: What is appropriate and what is not. ITiCSE'97 Working Group Reports and Supplemental Proceedings, p. 27-37.

Lemke, C. (2005). Modelos de Equações Estruturais com Ênfase em Análise Fatorial Confirmatória no Software AMOS. Universidade Federal do Rio Grande do Sul - [S.I.]. 2005.

Lee-Post, A. (2009). E-learning Success Model: an information systems Perspective. Electronic Journal of e-learning, v. 7, n. 1, p. 61-70. 
Liaw, S. S. et al. (2006). Attitudes toward search engines as a learning assisted tool: approach of Liaw and Huang's research model. Computers in Human Behavior, v.22, p. 177-190.

Liaw and Huang, H. M. (2003). An investigation of user attitudes toward search engines as an information retrieval tool. Computers in Human Behavior, v. 19, p. 751-765.

Lin, H. F. (2007). Measuring online learning systems success: applying the updated DeLone and McLean model. Cyber Psychology \& Behavior, v. 10, n. 6, p. 817-820.

Maroco, J. (2010). Análise de Equações Estruturais: Fundamentos teóricos, software e aplicações. Report Number: Pêro Pinheiro.

Marterns, M. P. and Haase, R. F. (2006). Advanced applications of structural equation modeling in counseling psychology research. The Counseling Psychologist, v. 34, n. 6, p. 878-911.

Maruyama, G. M. et al. (1998). Basics of Structural Equation Modeling. Sage Publications ed. London: [s.n.].

Mason, R. and Rennie, F. (2006). Elearning: The key concepts. London; New York: Routledge, p. xxxviii, 158 p.

McClelland, B. (2001). Digital learning and teaching: Evaluation of developments for students in higher education. European Journal of Engineering Education, v. 26, n. 2, p. 107-115.

Motiwallo, L. and Tello, S. (2000). Distance learning on the Internet: An exploratory study. The Internet and Higher Education, v. 2, n. 4, p. 253-264, 2000.

Mueller, D. and Strhmeier, S. No Title. (2011). Computers \& Education, v. 57, p. 25052516.

Mueller and Zimmermann, V. (2009). A learner-centered design, implementation, and evaluation approach of learning environments to foster acceptance. International Journal of Advanced Corporate Learning, v. 2, n. 3, p. 50-57.

Owston, R. D. and Wideman, H. H. (1998). Teacher factors that contribute to the implementation success in telelearning network. Center for the Study of Computers in Education Technical Report 98-3. Toronto, Canada: Faculty of Education, York University.

Ozkan, S. and Kösler, R. (2009). Multi-dimensional students' evaluation of e-learning systems in the higher education context: an empirical investigation. Computers \& Education, v. 53, n. 4, p. 1285-1296.

Pinsonneault, A. and Kraemer, K. L. (1993). Survey research in management information systems: An assessment. Journal of Management Information System.

Pittinsky, M. and Chase, B. (2000). Quality on the line: Benchmarks for success in Internet-based distance learning. The Institute for Higher Education Policy. Washington, DC: National Education Association: [s.n.]. 
Poelmans, S. et al. (2012). Usability and acceptance of e-learning in statistics education, based on the compendium platform. In Proceedings of the International Conference of Education, Research and Innovation (p. 1-10), 2008. Available at the following address http://www.wessa.net/download/iceripaper1.pdf Accessed: Nov, 13th.

Rosenberg, M. J. (2001). E-learning: Strategies for delivering knowledge in the digital age. New York: McGraw-Hill, p. xxiv, 344.

Roca, J. C., Chiu, C. M., and Martinez, F. J. (2006). Understanding e-learning continuance intention: an extension of the technology acceptance model. International Journal of Human-Computer Studies, v. 64, p. 683-696.

Savenye, W. C.; Olina, Z., and Niemczyk, M. (2001). So you are going to be an online writing teacher: Issues in designing, developing, and delivering an online course. Computers and Composition, v. 18, n. 1, p. 371-385.

Seddon, P. B. A. (1997). respecification and extension of the DeLone and McLean model of IS success. Information Systems Research, v. 8, n. 3, p. 240-253.

Shee, D. and WANG, Y. (2008). Multi-criteria evaluation of the web-based e-learning system: a methodology based on learner satisfaction and its applications. Computers \& Education, v. 50, n. 3, p. 894-905.

Sitzmann, T. et al. (2006). The comparative effectiveness of web-based and classroom instruction: a meta-analysis. Personnel Psychology, v. 59, p. 623-664.

Smith, L. J. (2001). Content and delivery: A comparison and contrast of electronic and traditional MBA marketing planning courses. Journal of Marketing Education, v. 23, n. 1, p. 35-44.

Sommerville, I. (2007). Engenharia de software. 8. ed. São Paulo: Pearson AddisonWesley.

TEH, G. P. L. (1999). Assessing student perceptions of Internet-based online learning environment. International Journal of Instructional Media, v. 26, n. 4, p. 397-402.

Van Aken, J. E. (2005). Management research as a design science: articulating the research products of mode 2 knowledge production in management. British Journal of Management, v. 16, n. 1, p. 19-36.

Venkatesh, V.; BALA, H. (2008). Technology acceptance model 3 and a research agenda on interventions. Decision Sciences, v. 39, n. 2, p. 273-315.

Wang, Y. S. (2003). Assessment of learner satisfaction with asynchronous electronic learning systems. Information \& Management, v. 41, p. 75-86. 
Wang, Wang, H. Y., and Shee, D. Y. (2007). Measuring e-learning systems success in an organizational context: Scale development and validation. Computers in Human Behavior, v. 23, p. 1792-1808.

Wang, W. T. and Wang, C. C. (2009). An empirical study of instructor adoption of webbased learning systems. Computers \& Education, v. 53, p. 761-774.

Wu, J.H., \& Wang, Y. M. (2006). Measuring KMS success: a respecification of the DeLone and McLean"s model. Information \& Management, 43(6), 728-739.

Yeung, P. and Jordan, E. (2007). The continued usage of business e-learning courses in Hong Kong corporations. Education and Information Technologies, v. 12, n. 3, p. 175-188. 